\title{
Influence of Collection Frequency on the Quality of Ejaculates from Large White and Pietrain Boars
}

\author{
Vasile MICLEA $^{1 *}$, Ilona GYORGY ${ }^{2}$, Ileana MICLEA ${ }^{1}$, Marius ZĂHAN ${ }^{1}$, Alexandru NAGY ${ }^{3}$, Aurel POTRA ${ }^{1}$ \\ ${ }^{1}$ Department of Animal Reproduction, University of Agricultural Sciences and Veterinary Medicine \\ Cluj-Napoca, Romania. \\ ${ }^{2}$ S.C.SEMTEST BVN S.A. Târgu Mureş, Romania. \\ ${ }^{3}$ SCDA Turda, Romania. \\ * corresponding author: vasilemiclea21@yahoo.com
}

Bulletin UASVM Animal Science and Biotechnologies 73(2)/ 2016

Print ISSN 1843-5262; Electronic ISSN 1843-536X

DOI:10.15835/buasvmcn-asb: 12207

\begin{abstract}
Semen from Large White and Pietrain boars was collected at 3 and 4 day intervals. Volume, percentages of live, immature and motile spermatozoa and tail abnormalities were evaluated in order to assess ejaculate quality. The number of insemination doses per ejaculate was calculated for each breed and collection frequency. Reducing the interval between collections doesn't modify ejaculate volume and spermatozoa motility but it increases the percentage of gametes that are immature or have an abnormal tail. A collection frequency of 3 days is better because the number of insemination doses per year is higher.
\end{abstract}

Keywords: boars, ejaculates, frequency, quality

\section{INTRODUCTION}

Numerous studies have investigated factors which influence the quality of boar semen. One example is the the work of Alberne and Kirkwood (1985) who have evaluated the influence of feed on swine reproduction while Alm et al. (2006) have estimated the fertility of sows inseminated with different semen doses. Nacu et al. (2008) harvested semen at 2, 3, 4 or 6 day intervals and analysed its quality. Tăpăloagă et al. (2008) measured the morphological characteristics of boar sperm cells form ejaculates collected at 2, 3 or 4 days. Miclea et al. (2007; 2008a; 2008b) have studied the influence of collection frequency on the quality of ejaculates from boars aged 3, 4 and 7 years.

Assessing the quality of sperm cells used for artificial insemination is of the outmost importance for semen processing. The number and quality of insemination doses has a major influence on the economic results of swine breeding farms.

\section{MATERIALS AND METHODS}

Ejaculates were collected during two consecutive years from Large White and Pietrain boars aged 3 and 4 years. The breeds were chosen because they are in very high demand on the semen market. Ages were chosen because previous research has proven that in males aged 3 and 4 years ejaculate quality and volume are the highest.

Ejaculates were collected at 3 or 4 day intervals. A number of 90 ejaculates were collected at 3 day intervals from Large White boars while 107 ejaculates were collected from Pietrain males. For the 4 day collection frequency 63 ejaculates were collected from Large White boars and 77 from Pietrain. Ejaculate volume was evaluated by weighing while sperm cell concentration was assessed using photometry. Spermatozoa motility was expressed as percentages. For 6 ejaculates collected from Large White animals and 9 ejaculates collected from Pietrain boars at a 3 day interval 
Tab. 1. Characteristics of ejaculates from Large White boars

\begin{tabular}{ccccccc}
\hline \multirow{2}{*}{ Characteristics } & \multicolumn{2}{c}{ Collected at 3 days } & \multicolumn{3}{c}{ Collected at 4 days } \\
\cline { 2 - 7 } & $\mathrm{x} \pm \mathrm{sx}$ & $\mathrm{s}$ & $\mathrm{v} \%$ & $\mathrm{x} \pm \mathrm{sx}$ & $\mathrm{s}$ & $\mathrm{v} \%$ \\
\hline Volume $-\mathrm{ml}$ & $266.00 \pm 6.40$ & 60.79 & 22.79 & $251.00 \pm 8.29$ & 65.84 & 26.21 \\
\hline Concentration $-\mathrm{n} \times 10^{6}$ & $230.00 \pm 14.91$ & 141.49 & 61.39 & $302.00 \pm 10.49$ & 83.31 & 27.57 \\
\hline $\begin{array}{c}\text { No. of sperm cells in the } \\
\text { ejaculate }-\mathrm{n} \times 10^{9}\end{array}$ & $70.72 \pm 2.73$ & 29.91 & 36.63 & $76.27 \pm 3.60$ & 28.59 & 4.72 \\
\hline Motility - \% & 72.11 & - & - & 72.47 & - & - \\
\hline Number of doses & $23.45 \pm 0.90$ & 8.58 & 36.58 & $25.00 \pm 1.19$ & 9.44 & 37.71 \\
\hline
\end{tabular}

Tab. 2. Characteristics of spermatozoa from Large White boars

\begin{tabular}{ccccccc}
\hline \multirow{2}{*}{ Characteristics } & \multicolumn{3}{c}{ Collected at 3 days } & \multicolumn{3}{c}{ Collected at 4 days } \\
\cline { 2 - 7 } & $\mathrm{x} \pm \mathrm{sx}$ & $\mathrm{s}$ & $\mathrm{v} \%$ & $\mathrm{x} \pm \mathrm{sx}$ & $\mathrm{s}$ & $\mathrm{v} \%$ \\
\hline Live sperm cells $-\%$ & $94.41 \pm 1.18$ & 2.90 & 3.07 & $96.50 \pm 0.76$ & 1.71 & 1.77 \\
\hline Dead sperm cells $-\%$ & $5.58 \pm 1.18$ & 2.90 & 51.97 & $3.40 \pm 0.76$ & 1.71 & 50.29 \\
\hline Immature sperm cells $-\%$ & $2.83 \pm 0.40$ & 1.00 & 35.33 & $1.70 \pm 0.40$ & 0.90 & 52.94 \\
\hline Tail abnormalities & $2.91 \pm 0.59$ & 1.46 & 50.17 & $1.80 \pm 0.64$ & 1.44 & 80.00 \\
\hline
\end{tabular}

we calculated percentages of dead and immature sperm cells and those with tail abnormalities. The same parameters were assessed for 5 Large White and 10 Pietrain ejaculates collected at a 4 day interval.

The number of insemination doses was calculated by dividing each ejaculate in $100 \mathrm{ml}$ portions that contained $3 \times 10^{9}$ sperm cells.

Results were analysed using that analysis of variance and were organised in tables depending on race.

\section{RESULTS AND DISCUSSION}

Ejaculates collected from Large White boars every 3 days had a high quality and could be processed for insemination in sows (Tab. 1).

Sperm cell characteristics also had fairly low levels (Tab. 2). Dead sperm cells were counted at $5.58 \%$, immature spermatozoa at $2.83 \%$ while tail abnormalities were observed in $2.91 \%$. The sum of these percentages amounts to $11.32 \%$, which is characteristic for good quality semen.

Reducing collection frequency resulted in a higher sperm cell concentration, a higher percentage of live gametes together with lower percentages of dead, immature and abnormal spermatozoa. The overall percentage of anomalous cells was $6.90 \%$ (Tab. 2).
The average number of insemination doses per ejaculate was 23.45 for the 3 day collection interval and 25.00 for the 4 day interval (Tab. $1)$. Improving ejaculate quality while reducing collection frequency should increase the number of doses per ejaculate. The number of ejaculates/ year is higher when collecting at 3 days compared with 4 days which results in a higher number of doses.

The dynamic of ejaculate quality was similar in Pietrain and Large White boars when collection frequency decreased (Tab. 3).

For both collection frequencies ejaculates from Pietrain boars had a lower volume and a smaller number of live sperm cells (Tab 4). This caused a reduction in the number of insemination doses per ejaculate.

\section{CONCLUSION}

In both breeds increasing collection frequency did not alter ejaculate volume and sperm cell motility.

Reducing collection frequency increases percentages of live sperm cell while decreasing percentages of gametes that are immature or have abnormal tails.

In both breeds and during the course of a year the number of insemination doses per ejaculate 
Tab. 3. Characteristics of ejaculates from Pietrain boars

\begin{tabular}{ccccccc}
\hline \multirow{2}{*}{ Chatracteristics } & \multicolumn{3}{c}{ Collected at 3 days } & \multicolumn{3}{c}{ Collected at 4 days } \\
\cline { 2 - 7 } & $\mathrm{x} \pm \mathrm{sx}$ & $\mathrm{s}$ & $\mathrm{v} \%$ & $\mathrm{x} \pm \mathrm{sx}$ & $\mathrm{s}$ & $\mathrm{v} \%$ \\
\hline Volume $-\mathrm{ml}$ & $211.00 \pm 6.87$ & 71.11 & 33.68 & $214.00 \pm 8.00$ & 70.70 & 32.97 \\
\hline Concentration $-\mathrm{n} \times 10^{6}$ & $343.00 \pm 12.84$ & 132.85 & 38.72 & $379.00 \pm 41.21$ & 178.13 & 46.99 \\
\hline $\begin{array}{c}\text { No. of sperm cells in the } \\
\text { ejaculate }-\mathrm{n} \times 10^{9}\end{array}$ & $66.89 \pm 2.39$ & 24.79 & 37.06 & $75.06 \pm 0.57$ & 25.59 & 34.09 \\
\hline Motility - \% & 74.11 & - & - & 73.83 & - & - \\
\hline Number of doses & $22.24 \pm 0.74$ & 7.75 & 34.84 & $24.71 \pm 0.75$ & 6.64 & 26.87 \\
\hline
\end{tabular}

Tab. 4. Characteristics of spermatozoa from Pietrain boars

\begin{tabular}{ccccccc}
\hline Characteristics & \multicolumn{2}{c}{ Collected at 3 days } & \multicolumn{2}{c}{ Collected at 4 days } \\
\cline { 2 - 7 } & $\mathrm{x} \pm \mathrm{sx}$ & $\mathrm{s}$ & $\mathrm{v} \%$ & $\mathrm{x} \pm \mathrm{sx}$ & $\mathrm{s}$ & $\mathrm{v} \%$ \\
\hline Live sperm cells - \% & $92.50 \pm 1.29$ & 3.89 & 4.20 & $95.20 \pm 0.78$ & 2.47 & 2.59 \\
\hline Dead sperm cells - \% & $7.50 \pm 1.29$ & 3.89 & 51.86 & $4.79 \pm 0.78$ & 2.47 & 51.56 \\
\hline Immature sperm cells - \% & $3.05 \pm 0.75$ & 2.25 & 73.77 & $0.90 \pm 0.20$ & 0.65 & 72.22 \\
\hline Tail abnormalities & $3.18 \pm 0.62$ & 1.77 & 55.66 & $2.01 \pm 0.37$ & 1.17 & 58.20 \\
\hline
\end{tabular}

is higher when semen was collected at a 3 day interval.

\section{Acknowledgments}

This work was supported by grant ADER 5.1.6/2015 funded by the Ministry of Agriculture and Rural Development, Romania.

\section{REFERENCES}

1. Alberne FX, Kirkwood RN (1985). Nutrition and sow prolificacy. J Reprod Fertil Suppl 33:169-183.

2. Alm K, Peltoniemi O, Koskinen E, Andersson M (2006). Porcine field fertility with two different insemination doses and the effect of sperm morphology. Reprod Dom Anim, 41:143-172.

3. Miclea V, Zăhan M, Miclea I, Vajda I (2007). Influence of harvest frequency on the quality of boar semen. Bull
UASVM Cluj-Napoca Animal Science and Biotechnologies 63-64:95-98.

4. Miclea V, Zăhan M, Miclea I, Vajda I (2008a). Influence of daily collection on ejaculate quality from Pietrain boars. Scientifical papers Animal Sciences and Biotechnologies USAMV a Banatului Timișoara 41:122-126.

5. Miclea V, Zăhan M, Gyorgy I, Miclea I (2008b). Influence of boar age on ejaculate quality. Bull UASVM Cluj-Napoca Animal Science and Biotechnologies 65(1-2):99-103.

6. Nacu G (2008). Researches concerning the sperm production according to the frequency of collecting the seminal material at boars. Lucrări Ştiințifice Zootehnie USAMV Iaşi 51:362-365

7. Tăpăloagă D, Tăpăloagă PR, Neagu I, Culea C, Mitrănescu E, Simion VE, Rotaru E (2008). Influence of collecting rhythm on boar sperm cells quality in Large White and Landrace boars. Bull UASVM Cluj-Napoca Animal Science and Biotechnologies 65(1-2):114-118. 